\title{
Cumulative Cytotoxicity Assay of the Aqueous and Ethanolic Extracts of the Selected Medicinal Plants Using Crown Gall Tumor Disc Bioassay ${ }^{\dagger}$
}

\author{
Sandeep Waghulde ${ }^{1, *}$, Nilesh Gorde ${ }^{1}$, Tushar Baviskar ${ }^{1}$, Praful Patil ${ }^{1}$, Shweta Singh ${ }^{1}$, Mohan K. Kale ${ }^{1}$ and \\ Vijay R. Patil ${ }^{2}$
}

Citation: Waghulde, S.; Gorde, N.; Baviskar, T.; Patil, P.; Singh, S.; Kale, M.K.; Patil, V.R. Cumulative Cytotoxicity Assay of the Aqueous and Ethanolic Extracts of the Selected Medicinal Plants Using Crown Gall Tumor Disc Bioassay. Chem. Proc. 2021, 3, 136. https:// doi.org/10.3390/ecsoc-24-08297

Academic Editors: Julio A. Seijas and M. Pilar Vázquez-Tato

Published: 14 November 2020

Publisher's Note: MDPI stays neutral with regard to jurisdictional claims in published maps and institutional affiliations.

Copyright: ( $) 2020$ by the authors. Licensee MDPI, Basel, Switzerland. This article is an open access article distributed under the terms and conditions of the Creative Commons Attribution (CC BY) license (http://creativecommons.org/licenses/by/4.0/).
1 Konkan Gyanpeeth Rahul Dharkar College of Pharmacy and Research Institute, Karjat, Raigad 410201, India; nileshgorde83@gmail.com (N.G.); tusharbaviskar21@gmail.com (T.B.); ppraful1011@gmail.com (P.P.); shwetasingh996@gmail.com (S.S.); kalemkpharm@gmail.com (M.K.K.)

2 Hon'ble Loksevak Madhukarrao Chaudhari College of Pharmacy, Faizpur, Jalgaon 425503, India; drvrpatil@gmail.com

* Correspondence: sandeepwaghulde@yahoo.com

+ Presented at the 24th International Electronic Conference on Synthetic Organic Chemistry, 15 November-15 December 2020; Available online: https://ecsoc-24.sciforum.net/.

\begin{abstract}
The present study was carried out to test an in vivo crown gall tumor disc bioassay using potato discs of the aqueous and ethanolic extracts of Annona reticulata with Allium sativum, Allium fistolisum, Brassica oleraceae, and then correlate the cytotoxicity results with the known pharmacological activities of the plants. Cytotoxicity was evaluated according to the crown gall tumor disc bioassay, a highly specific, quantitative method that requires only a short period of time to return results of crown gall tumor formation. The results shows the cumulative activity of the extracts of Annona reticulate extract with Allium sativum, Allium fistolisum and Brassica oleraceae extracts and shown they were potent against the bioassay as compared to their being used alone with combined extracts. The results indicated that their bioactive components have considerable pharmacological effects. Thus, the results supported the uses of these plant species in traditional medicine.
\end{abstract}

Keywords: crown gall tumor disc bioassay; Annona reticulate; Allium sativum; Allium fistolisum and Brassica oleraceae; potato disc bioassay; antitumour; cytotoxicity

\section{Introduction}

Crown gall is a neoplastic disease of plants that occurs in more than 60 families of dicotyledons and many gymnosperms. The disease is characterized by the transformation of normal plant cells into autonomous tumor cells in a short period of time. Once initiated, the tumor possesses the capacity for autonomous growth independent of the normal control mechanism of the host [1]. The causative agents of this disease are specific strains of the Gram-negative bacterium Agrobacterium tumefaciens [2]. The relevance of the crown gall tumor system to the general cancer problem has been thoroughly reviewed $[3,4]$. The use of highly specific, quantitative bioassays that require only a short period of time to obtain results are available for studying crown gall tumor formation $[5,6]$. Using the potato disc bioassay we examined extracts and purified compounds of plant origin, some of which had shown antitumor activity in animals, for their effect on the initiation of crown gall tumors.

The first step in a drug discovery is the screening of biological and synthetic bioactive compounds [7]. The potato-disc assay is one of the methods that has proven to be useful in checking molecules' known and novel antitumor properties. This bioassay was based on Agrobacterium tumefaciens infection on a potato disc [8]. The tumorogenic mechanism 
that it initiated in plant tissues was in many ways similar to that found in animals [9]. $A$. tumefaciens, a rod-shaped and virulent Gram-negative soil-borne bacterium, is the causative agent of crown gall disease. It is a neoplastic disease that produces tissue masses that bulge from the stems and roots of woody and herbaceous plants. These tumor masses could be spongy or hard, with or without a deleterious effect on the plant. The tumor produced is histologically similar to those in animals or humans. Ti-plasmid produces cell proliferation and blocks apoptosis by tumor induction just as in animal or human cancer cells [10]. As a result, it was proposed that the crown gall tumor (potato disc) assay be used to prescreen for antitumor activity [11-13]. Although a lot of aseptic technique is required to carry out the procedure, it can be performed with minimal technical training.

A variable chemical that interferes with cell cycles and has different modes of action was sensitive for the antitumor potato disc assay [14]. Therefore, a simple test is performed that needs aseptic conditions and it permits the detection and isolation of many anti-tumor compounds from plant microbes or biomolecules that were confirmed by in vivo animal tumor inhibition [15].

\section{Materials and Methods}

The leaves of $A$. reticulate, Allium sativum (bulbs), A. fistolisum and B. Oleraceae were collected from the town of Karjat, Raigad District, Maharashtra, India, in December 2018. All plant materials were authenticated at "The Blatter Herbarium" at St. Xavier's College, Mumbai.

For the experiment, the leaves of the plants were collected after being identified and authenticated. They were shade-dried and made into a coarse powder that was first defatted with petroleum ether and then subjected to cold maceration for $72 \mathrm{~h}$ using a 1:1 mixture of methanol and water as a solvent to prepare a hydro-alcoholic extract of Annonareticulata leaves (percentage yield $20.5 \% w / w$ with respect to dried powder). The extract was filtered and then concentrated by a rotary evaporator. For the preparation, the different fractions were used [16-18].

The sun-dried and powdered leaves (76 g) of A. reticulata were successively extracted in a Soxhlet extractor at an elevated temperature $\left(40-60{ }^{\circ} \mathrm{C}\right)$ using $200 \mathrm{~mL}$ of distilled n-hexane followed by extraction of different solvent like petroleum ether, methanol, and chloroform. All extracts were collected and filtered independently through filter paper and transferred in petri dishes so that liquid solvents could evaporate to give dry extracts. These were weighed and stored in an air-tight container with the necessary identification markings and kept in a refrigerator for future investigation.

Ten grams of spring onion leaves or bulbs were soaked in $100 \mathrm{~mL}$ of methanol and water, respectively. The prepared samples were shaken using orbital shaker for $7 \mathrm{~h}$ followed by centrifugation for $15 \mathrm{~min}$ at $7000 \mathrm{rpm}$. The extracts were then filtered using a vacuum filtration assembly and assessed using a brine shrimp lethality bioassay.

Red cabbage leaves were shade-dried followed by drying in a hot air oven at $50{ }^{\circ} \mathrm{C}$ and then ground into a fine powder and stored in an air-tight container for analysis. Fresh red cabbage leaves were ground in the mixer to collect ice. The coarse powder and juice of the red cabbage were extracted using methanol and water. These extracts of red cabbage powder and juice were collected separately and filtered using Whatman filter paper. All extracts were concentrated and excessive solvents were evaporated in a vacuum.

\subsection{Phytopathogenicity Test}

Phytopathogenicity tests were done using potato disc bioassays [19]. The strain of $A$. tumefaciens used for the tumor induction was obtained from the National Collection of Industrial Microorganisms (Pune 2145, India). 


\subsection{Disc Bioassay Method}

The Luria Bertani (LB) agar medium was used to prepare the culture of A. tumefaciens strains. A single colony was transferred into the LB broth medium and incubated at $30^{\circ} \mathrm{C}$ for $24 \mathrm{~h}$. Potatoes (Solanum tuberosum L.) were disinfested by scrubbing under running water with a brush and then immersed in $2 \%$ Clorox for $5 \mathrm{~min}$. Potato discs, $(5 \mathrm{~mm} \times 8 \mathrm{~mm})$ were made using a cork borer and immersed in $2 \%$ Clorox for $30 \mathrm{~min}$. Each disc was rinsed thrice in autoclaved distilled water for $15 \mathrm{~min}$. After washing and rinsing, the potato discs were removed from the distilled water and blotted on sterile paper towels to remove excess water. In all, 16 potato discs were kept in the petri plates containing an autoclaved agar medium (2\%). Suspensions of $A$. tumefaciens on the LB broth medium were standardized. Each disc was overlain with $50 \mu \mathrm{L}$ of bacterial suspension. Petri plates were sealed by parafilm and incubated at room temperature $\left(25-30^{\circ} \mathrm{C}\right)$. The experiment was repeated at least twice and used with 10 replications. After 21 days, the potato discs were stained with Lugol's solution $\left(10 \% \mathrm{KI}+5 \% \mathrm{I}_{2}\right)$ and the tumors were counted under a dissecting microscope [20]. Lugol's reagent stained the starch in the potato tissue dark-blue to darkbrown, but the tumors produced by A. tumefaciens did not take up the stain and appeared creamy to orange [21-23]

Percentage inhibition $=100-($ number of tumor with sample/number of tumor with control) $\times 100$

\subsection{Statistical Analysis}

Experiments were Performed in triplicates and data were analyzed by taking their mean.

\section{Results and Discussion}

Table 1 lists the effects of all of the samples tested on the initiation of crown gall tumors on potato discs. The samples are listed in the experimental order in which they were assayed. A definite correlation exists between tumor formation of these samples, and their ability to inhibit crown gall tumor formation on the potato discs. Data from a typical experiment are shown in (Table 2) as a percent inhibition. Each sample was assayed in triplicate experiments. The initial step in the formation of crown gall tumors involved the attachment of the bacterium to a tumor-binding site [24,25]. The amount of inhibition obtained with the active samples was consistent whether or not these extracts were added to the potato discs. These results eliminated any possible effects of these samples on bacterial attachment.

Table 1. Comparative activity of various plant materials against initiation of crown gall tumors for cytotoxicity.

\begin{tabular}{cccc}
\hline Plant Extracts & \multicolumn{3}{c}{ Mean Number of Tumors (Mean \pm SE) } \\
\hline Concentrations & $\mathbf{1 ~} \mathbf{~ g} / \mathbf{m L}$ & $\mathbf{1 0} \mathbf{~ m g} / \mathbf{m L}$ & $\mathbf{5 0} \mathbf{~ m g} / \mathbf{m L}$ \\
\hline Control (Distilled water) & 0.0 & 0.0 & 0.0 \\
Control (DMSO) & $18.66 \pm 2.25$ & $21.33 \pm 2.28$ & $23.33 \pm 1.85$ \\
Standard (Colchicine) & $9.66 \pm 1.90$ & $11.33 \pm 0.78$ & $14.33 \pm 1.13$ \\
Annona reticulate (Alcoholic extracts) & $9.00 \pm 0.33$ & $11.67 \pm 0.87$ & $14.67 \pm 0.62$ \\
Annona reticulate (Aqueous extract) & $7.33 \pm 0.11$ & $8.67 \pm 0.40$ & $9.33 \pm 0.62$ \\
Allium sativum (Alcoholic) & $8.33 \pm 0.11$ & $11.67 \pm 0.59$ & $15.00 \pm 0.67$ \\
Allium sativum (Aqueous extract) & $6.00 \pm 0.58$ & $7.33 \pm 0.87$ & $9.33 \pm 0.29$ \\
Allium fistolisum (Alcoholic extracts) & $9.00 \pm 0.58$ & $8.67 \pm 0.95$ & $11.00 \pm 1.20$ \\
Allium fistolisum (Aqueous extract) & $9.00 \pm 1.20$ & $10.67 \pm 0.95$ & $13.67 \pm 0.87$ \\
Brassica oleraceae (Alcoholic extracts) & $7.00 \pm 0.33$ & $12.33 \pm 1.18$ & $14.33 \pm 0.11$ \\
Brassica oleraceae (Aqueous extract) & $8.66 \pm 0.62$ & $1.00 \pm 0.67$ & $13.33 \pm 0.73$ \\
Annona reticulate and Allium sativum (1:1) Alcoholic extracts & $13.00 \pm 1.20$ & $16.00 \pm 1.20$ & $20.33 \pm 1.74$
\end{tabular}


Annona reticulate and Allium satioum (1:1) Aqueous extracts

\begin{tabular}{ccc}
$6.66 \pm 0.87$ & $8.33 \pm 0.59$ & $10.33 \pm 0.91$ \\
$12.00 \pm 0.58$ & $14.67 \pm 0.97$ & $15.67 \pm 1.24$ \\
$9.00 \pm 0.33$ & $11.67 \pm 0.80$ & $12.67 \pm 0.48$ \\
$5.66 \pm 0.29$ & $8.33 \pm 0.87$ & $9.33 \pm 0.48$ \\
$5.33 \pm 0.62$ & $6.67 \pm 0.91$ & $7.67 \pm 1.24$ \\
\hline
\end{tabular}
Allium fistolisum and Annona reticulate (Alcoholic extracts) Allium fistolisum and Annona reticulate (Aqueous extract) Brassica oleraceae and Annona reticulate (Alcoholic extracts) Brassica oleraceae and Annona reticulata (Aqueous extract)

Table 2. Comparative \% inhibition of crown gall tumors for cytotoxicity.

\begin{tabular}{|c|c|c|c|}
\hline Plant Extracts & \multicolumn{3}{|c|}{ \% Inhibition of Tumors When Compared with Control } \\
\hline Concentrations & $1 \mathrm{mg} / \mathrm{mL}$ & $10 \mathrm{mg} / \mathrm{mL}$ & $50 \mathrm{mg} / \mathrm{mL}$ \\
\hline Standard (Colchicine) & 51.78 & 53.13 & 61.44 \\
\hline Annona reticulate (Alcoholic extracts) & 48.21 & 54.70 & 62.87 \\
\hline Annona reticulate (Aqueous extract) & 39.28 & 40.63 & 41.43 \\
\hline Allium sativum (Alcoholic) & 44.63 & 54.70 & 64.29 \\
\hline Allium sativum (Aqueous extract) & 32.14 & 34.38 & 40.01 \\
\hline Allium fistolisum (Alcoholic extracts) & 48.21 & 51.57 & 54.29 \\
\hline Allium fistolisum (Aqueous extract) & 48.21 & 50.01 & 58.58 \\
\hline Brassica oleraceae (Alcoholic extracts) & 37.49 & 57.82 & 61.44 \\
\hline Brassica oleraceae (Aqueous extract) & 46.42 & 46.88 & 57.15 \\
\hline Annona reticulate and Allium sativum (1:1) Alcoholic extracts & 69.63 & 75.01 & 87.16 \\
\hline Annona reticulate and Allium satioum (1:1) Aqueous extracts & 35.71 & 39.07 & 44.29 \\
\hline Allium fistolisum and Annona reticulate (Alcoholic extracts) & 64.27 & 68.76 & 67.15 \\
\hline Allium fistolisum and Annona reticulate (Aqueous extract) & 48.21 & 54.70 & 54.29 \\
\hline Brassica oleraceae and Annona reticulate (Alcoholic extracts) & 30.35 & 39.07 & 40.01 \\
\hline Brassica oleraceae and Annona reticulata (Aqueous extract) & 28.57 & 31.25 & 32.86 \\
\hline
\end{tabular}

Statistical analysis showed that the methanol extract inhibited tumor growth on the potato discs significantly in a concentration-dependent manner across the strains (Table 1). A highly significant difference was observed, and agrobacterium suggests their different activity (Table 1). Maximum tumor inhibition was observed at $50 \mathrm{mg} / \mathrm{mL}$ plant extract against the strain. No significant tumor inhibition was observed at $1 \mathrm{mg} / \mathrm{mL}$ concentration. The inhibition percentage was calculated to compare with the control. On the basis of tumor forming ability, it was observed that A. tumefaciens inhibited the tumour growth. Our study results showed that an alcoholic extract significantly inhibited tumor formation on potato discs, which indicates it could be used for its antitumor properties. Several workers conducted similar types of investigations and recommended a large number of plant extracts as a potential source of anticancer agents [26]. Crown gall is a neoplastic disease of plants caused by Agrobacterium tumefaciens [27]; which occurs in more than 60 families of dicotyledons and many gymnosperms. Due to a similar mechanism of tumor development for both cases, we concluded that our studied plant extract might be of use for drug development for tumor treatment in humans.

\section{Conclusions}

Annona reticulate had been reported to be a potential antitumor agent for a long time, and the present study confirmed the cumulative effect of its antitumor potential. Significant tumor inhibition by an alcoholic extract of Annona reticulate on potato discs at different concentrations may lead to the conclusion that it might be used as a potential source of an antitumor agent.

Institutional Review Board Statement: This study was approved by the Institutional Review Board (IRB) of, Konkan Gyanpeeth Rahul Dharkar College of Pharmacy and Research Institute, Karjat, and the protocols used in the study were approved by the Committee.

Informed Consent Statement: Not applicable. 
Data Availability Statement: The authors confirm that the data supporting the findings of this study are available within the article and its supplementary materials.

Acknowledgments: The authors acknowledge the Principal, Konkan Gyanpeeth Rahul Dharkar College of Pharmacy and Research Institute, Karjat for financial support.

Conflicts of Interest: Declared none.

\section{References}

1. Lippincott, J.A.; Lippincott, B.B. The Genus Agrobacterium and Plant Tumorigenesis. Annu. Rev. Microbiol. 1975, $29,377-405$.

2. Braun, A.C. The Relevance of Plant Tumor Systems to an Understanding of the Basic Cellular Mechanisms Underlying Tumorigenesis1. Neuronal Act. Tumor Tissue 1972, 15, 165-187.

3. Cloud, W. Stalking the wild crown-gall. In Readings in the Life Sciences Biology Anthology; Wilson, S., Roe, R., Eds.; West Publishing Co.: New York, NY, USA, 1974.

4. Anand, V.K.; Heberlein, G.T. Crown-gall tumorigenesis in potato tumor tissue. Am. J. Bot. 1977, 64, $153-158$.

5. Lippincott, J.A.; Heberlein, G.T. The quantitative determination of the infectivity of Agrobacterium tumefaciens. Am. J. Bot. $1965,52,863$.

6. Islam, M.S.; Akhtar, M.M.; Parvez, M.S.; Alam, M.J. Antitumor and antibacterial activity of a crude methanol leaf extract of Vitex negundo L. Arch. Biol. Sci. 2013, 65, 229-238.

7. Islam, M.S.; Akhtar, M.M.; Rahman, M.M.; Rahman, M.A.; Sarker, K.K.; Alam, M.F. Antitumor and phytotoxic activities of leaf methanol extract of Oldenlandia diffusa (Willd.) Roxb. Glob. J. Pharmacol. 2009, 3, 99-106.

8. Srirama, R.; Ramesha, G.; Ravikanth, R.U.S.; Ganeshaiah, K.N. Are plants with anti-cancer activity resistant to crown gall? A test of hypothesis. Curr. Sci. 2007, 95, 10-25.

9. Kempf, V.A.J.; Hitziger, N.; Riess, T.; Autenrieth, I.B. Do plant and human pathogens have a common pathogenicity strategy? Trends Microbiol. 2002, 10, 269-275.

10. David, S.G. Plants as models for the study of human pathogenesis. Biotechnol. Adv. 2004, 22, 363-382.

11. Jerry, L.M.; Lingling, L.R. The use of biological assays to evaluate botanicals. Drug Inf. J. 1998, 32, 513-524.

12. Galsky, A.G.; Wilsey, J.P.; Powell, R.G. Crown gall tumor disc bioassay: A possible aid in the detection of compounds with antitumor activity. Plant Physiol. 1980, 65, 184-185.

13. Ferrigni, N.R.; Putnam, J.E.; Anderson, B.; Jacobsen, L.B.; Nichols, D.E.; Moore, D.S.; McLaughlin, J.L.; Powell, R.G.; Smith, C.R., Jr. Modification and evaluation of the potato disc assay and antitumor screening of Euphorbiacae seeds. J. Nat. Prod. 1982, 45, 679-686.

14. Coker, P.S.; Radecke, J.; Guy, C.; Camper, N.D. Potato disc tumor induction assay: A multiple mode of drug action assay. Phytomedicine 2003, 10, 133-138.

15. McLaughlin, J.L. Crown gall tumors on potato discs and bine shrimp lethality: Two single bioassays for plant screening and fractionation. In Methods in Plant Biochemistry; Hostettmann, K., Ed.; Academic Press: London, UK, 1991.

16. Jia, Z.; Tang, M.; Wu J. The determination of flavanoid contents in mulberry and their scavenging effect on superoxide radicals. Food Chem. 1999, 64, 555-559.

17. Bondet, V.; Brand Williams, W.; Berset, C. Kinetics and Mechanisms of antioxidant activity using the DPPH free radical method. Lwt-Foodsci. Tech. 1997, 30, 609-615.

18. Brand-Williams, W.; Cuvelier, M.E.; Berset, C. Use of a free radical method to evaluate antioxidant activity. LWT Food Sci. Technol. 1999, 28, 25-30.

19. Kahl, G. Molecular biology of wound healing: The conditioning phenomenon. In Molecular Biology of Plant Tumors; Kahl, G., Schell, J.S., Eds.; Academic Press: New York, NY, USA, 1982; pp. 211-267.

20. Islam, M.S.; Rahman, M.M.; Rahman, M.A.; Qayum, M.A.; Alam, M.F. In vitro evaluation of Croton bonplandianum Baill.as potential antitumor properties using Agrobacterium tumefaciens. J. Agric. Technol. 2010, 6, 79-86.

21. Chen, F.C.; Hseu, S.H.; Hung, S.T.; Chen, M.C.; Lin, C.Y. Leaf, stem and crown galls on perennial asters caused by Agrobacterium tumefaciens in Taiwan. Bot. Bull. Acad. Sin. 1999, 40, 237-242.

22. Aysan, Y.; Sahin, F.; Mirik, M.; Donmez, M.F.; Tekman, H. First report of crown gall of apricot (Prunus armeniaca) caused by Agrobacterium tumefaciens in Turkey. Plant Pathol. 2003, 52, 793-793.

23. Hussain, A.; Zia, M.; Mirza, B. Cytotoxic and antitumor potential of Fagonia cretica L. Turk. J. Biol. 2007, 31, 19-24.

24. Glogowski, W.; Galsky, A.G. Agrobacterium tumefaciens site attachment as a necessary prerequisite for crown-gall tumor formation on potato discs. Plant. Physiol. 1978, 61, 1031-1033.

25. Lippincott, B.B.; Lippincott, J.A. Bacterial attachment to a specific wound site as an essential stage in tumor initiation by Agrobacterit $n$ tumefaciens. J. Bacteriol. 1969, 97, 620-628.

26. Turker, A.; Camper, N. Biological activity of Common Mullein, a medicinal plant. J. Ethnopharmacol. 2002, 82, 117-125. 10.1016/S0378-8741(02)00186-1.

27. Kahl, G.; Schell, J.S. Molecular Biology of Plant Tumors; Academic Press: Cambridge, MA, USA, 1982; pp. xix-xxi, ISBN 9780123943804, doi:10.1016/B978-0-12-394380-4.50005-0. 